\title{
Thermochemically Consistent Free Energies of Hydration for Di- and Trivalent Metal
} Ions

\section{Kepp, Kasper Planeta}

Published in:

Journal of Physical Chemistry Part A: Molecules, Spectroscopy, Kinetics, Environment and General Theory

Link to article, DOI:

10.1021/acs.jpca.8b06674

Publication date:

2018

Document Version

Peer reviewed version

Link back to DTU Orbit

Citation (APA):

Kepp, K. P. (2018). Thermochemically Consistent Free Energies of Hydration for Di- and Trivalent Metal lons. Journal of Physical Chemistry Part A: Molecules, Spectroscopy, Kinetics, Environment and General Theory, 122(37), 7464-7471. https://doi.org/10.1021/acs.jpca.8b06674

\section{General rights}

Copyright and moral rights for the publications made accessible in the public portal are retained by the authors and/or other copyright owners and it is a condition of accessing publications that users recognise and abide by the legal requirements associated with these rights.

- Users may download and print one copy of any publication from the public portal for the purpose of private study or research.

- You may not further distribute the material or use it for any profit-making activity or commercial gain

- You may freely distribute the URL identifying the publication in the public portal 
Subscriber access provided by DTU Library

\title{
A: Spectroscopy, Molecular Structure, and Quantum Chemistry
}

\author{
Thermochemically Consistent Free Energies \\ of Hydration for Di- and Trivalent Metal Ions \\ Kasper P. Kepp
}

J. Phys. Chem. A, Just Accepted Manuscript • DOI: 10.1021/acs.jpca.8b06674 • Publication Date (Web): 29 Aug 2018

Downloaded from http://pubs.acs.org on August 30, 2018

\section{Just Accepted}

"Just Accepted" manuscripts have been peer-reviewed and accepted for publication. They are posted online prior to technical editing, formatting for publication and author proofing. The American Chemical Society provides "Just Accepted" as a service to the research community to expedite the dissemination of scientific material as soon as possible after acceptance. "Just Accepted" manuscripts appear in full in PDF format accompanied by an HTML abstract. "Just Accepted" manuscripts have been fully peer reviewed, but should not be considered the official version of record. They are citable by the Digital Object Identifier (DOI®). "Just Accepted" is an optional service offered to authors. Therefore, the "Just Accepted" Web site may not include all articles that will be published in the journal. After a manuscript is technically edited and formatted, it will be removed from the "Just Accepted" Web site and published as an ASAP article. Note that technical editing may introduce minor changes to the manuscript text and/or graphics which could affect content, and all legal disclaimers and ethical guidelines that apply to the journal pertain. ACS cannot be held responsible for errors or consequences arising from the use of information contained in these "Just Accepted" manuscripts. 


\title{
Thermochemically Consistent Free Energies of Hydration for Di- and Trivalent Metal Ions
}

\author{
Kasper P. Kepp* \\ Technical University of Denmark, DTU Chemistry, Building 206, 2800 Kgs. Lyngby, DK - Denmark. \\ *Phone: +045 452524 09. E-mail: kpj@kemi.dtu.dk
}

\begin{abstract}
This paper uses the relationship between the standard half reduction potential, the third ionization potential, and the free energies of hydration $\left(\Delta \mathrm{G}_{\text {hyd }}\right)$ of $\mathrm{M}^{2+}$ and $\mathrm{M}^{3+}$ ions to calculate new values of $\Delta \mathrm{G}_{\text {hyd }}$ for $\mathrm{M}^{2+}$ and $\mathrm{M}^{3+}$ ions. The numbers are "thermochemically consistent", i.e. all numbers agree with the applied thermochemical cycle. This enables the tabulation of many $\Delta \mathrm{G}_{\mathrm{hyd}}$ derived mainly from the data compiled by Marcus, but consistent with $\Delta \mathrm{G}_{\mathrm{hyd}}\left(\mathrm{H}^{+}\right)=1100 \mathrm{~kJ} / \mathrm{mol}$ and SHE $=4.44 \mathrm{~V}$. The accuracy of the new values of $\Delta \mathrm{G}_{\mathrm{hyd}}\left(\mathrm{M}^{3+}\right)$ is by definition similar to the accuracy of the experimental hydration energy of the $\Delta \mathrm{G}_{\mathrm{hyd}}\left(\mathrm{M}^{2+}\right)$ used for calculation, and vice versa, i.e. the new data have the same accuracy or higher than previously reported. As a result, the literature values for $\mathrm{Cr}^{3+}$ and $\mathrm{Au}^{3+}$, and $\mathrm{Pd}^{2+}$ are substantially revised. The approach also allows the calculation of new $\Delta \mathrm{G}_{\text {hyd }}$ for metal ions such as $\mathrm{Mn}^{3+}, \mathrm{Ti}^{2+}, \mathrm{Ag}^{3+}, \mathrm{Ni}^{3+}, \mathrm{Cu}^{3+}, \mathrm{Au}^{2+}$, and the theoretically interesting but experimentally inaccessible +2 ions of lanthanides. The new numbers enable a discussion of the previously unreported trend in $\Delta \mathrm{G}_{\text {hyd }}\left(\mathrm{M}^{3+}\right)$ for the $3 \mathrm{~d}$ metal ions, which relates to the ligand field stabilization energies and effective nuclear charge as for the $\mathrm{M}^{2+}$ ions. The new tabulated values should be accurate with the applied assumptions to within $10 \mathrm{~kJ} / \mathrm{mol}$ and may be of value for other thermochemical calculations, for interpretation of the aqueous trend chemistry of the metal ions, and as benchmarks for theoretical chemistry.
\end{abstract}




\section{INTRODUCTION}

The hydrated metal ions play a central role in living systems and chemistry ${ }^{1}$, including many fields of catalysis $^{2}$ and in diseases such as Alzheimer's disease ${ }^{3}$. The hydration free energy $\Delta \mathrm{G}_{\mathrm{hyd}}\left(\mathrm{M}^{\mathrm{n}+}\right)$ greatly contributes to the chemistry of the metal ion in aqueous solution ${ }^{2,4}$. For example, $\Delta \mathrm{G}_{\text {hyd }}\left(M^{\mathrm{n}+}\right)$ is the price paid when transferring a metal ion such as $\mathrm{Ca}^{2+}$ to a protein channel in a membrane, or into a protein from solution. The difference in $\Delta \mathrm{G}_{\mathrm{hyd}}\left(\mathrm{M}^{\mathrm{n+}}\right)$ of two metal ions such as $\mathrm{Ca}^{2+}$ and $\mathrm{Mg}^{2+}$ or $\mathrm{Cd}^{2+}$ contributes substantially to the selectivity in their association as host-guest complexes. The $\Delta \mathrm{G}_{\text {hyd }}\left(\mathrm{M}^{\mathrm{n}+}\right)$ also contributes to the dynamic behavior of the metal ion in aqueous solution, its solubility, its tendency to form stabilizing interactions with macromolecules, and its effect on the structure of water itself $f^{1,5}$.

Experimental values of $\Delta \mathrm{G}_{\text {hyd }}$ also serve as important benchmark data for calculation of other properties, and for the evaluation of theoretical methods such as density functional theory (DFT) and classical force fields ${ }^{6,7}$. When theoretically studying metal ions it is of central importance that $\Delta \mathrm{G}_{\text {hyd }}$ of the charged species is consistently described, as errors in $\Delta \mathrm{G}_{\text {hyd }}$ translate into errors in its computed ensemble-averaged behavior, such as spurious formation of salt bridges or overestimated ion-water interactions; the transport of the ion through water studied by molecular dynamics also depends on the modeled tendency of the ion to stick in its current hydration shell depending on the magnitude of $\Delta \mathrm{G}_{\text {hyd }} 8,9$.

Most values of $\Delta \mathrm{G}_{\mathrm{hyd}}$ have been tabulated by Marcus ${ }^{10,11}$ using the tetraphenylarsonium tetraphenylborate (TATB) extra-thermodynamic assumption required to separate anion and cation hydration terms ${ }^{12}$. Many data have also been tabulated by other prominent researchers such as Noyes ${ }^{13}$, Rosseinsky ${ }^{14}$, Fawcett ${ }^{15}$, and Latimer ${ }^{16,17}$. Since the data by Marcus are the most abundant, they have been used in this work for deriving new free energies of hydration, but other data have also been considered in cases of disagreement, such as for $\mathrm{Cr}^{3+}$ (see below). Trasatti has explained in detail how to derive $\Delta \mathrm{G}_{\mathrm{hyd}}$ from the associated standard half potentials $\mathrm{E}_{\mathrm{y} / 2}{ }^{0}$ and ionization potentials (IP) ${ }^{18,19}$. The reverse transformation includes attempts to identify "absolute" half potentials based on the associated free energies of the thermochemical cycle ${ }^{18-20}$. Of major importance in this context are i) the adherence to consistent standard states (298.15 K; unity activity; 1 atm partial pressure); ii) the use of adequate values of $\Delta \mathrm{G}_{\mathrm{hyd}}\left(\mathrm{H}^{+}\right)$including consideration of the surface potential of water $\chi^{\mathrm{S}}$, with the consensus $\Delta \mathrm{G}_{\mathrm{hyd}}\left(\mathrm{H}^{+}\right)=-1100 \pm 3 \mathrm{~kJ} / \mathrm{mol}^{21,22}$; and iii) the applied convention for the potential of the standard hydrogen electrode (SHE) of $\mathrm{E}_{\text {SHE }}^{0}(\mathrm{abs})=+4.44 \mathrm{~V} \pm 0.02 \mathrm{~V}^{19}$. 
In this paper, thermochemical cycles using the IP, $\mathrm{E}_{1 / 2}^{0}$, and $\Delta \mathrm{G}_{\text {hyd }}$ have been used to derive new values of $\Delta \mathrm{G}_{\text {hyd }}$ that are all consistent with the $\mathrm{E}_{\text {SHE }}^{0}(\mathrm{abs})=+4.44 \mathrm{~V}$ and the hydration free energy of the proton $\Delta \mathrm{G}_{\mathrm{hyd}}\left(\mathrm{H}^{+}\right)=-1100 \mathrm{~kJ} / \mathrm{mol}$. In addition, the thermochemical cycle enables accurate estimation $( \pm 10 \mathrm{~kJ} / \mathrm{mol})$ of many $\Delta \mathrm{G}_{\mathrm{hyd}}$ values not previously reported. Since all values are derived from experimental data only, the new numbers have the same accuracy as the experiments used to evaluate $\Delta \mathrm{G}_{\text {hyd }}$ of the metal ion of the alternative oxidation state, or in some cases better, as explained in individual cases. Notably, the new $\Delta \mathrm{G}_{\text {hyd }}$ values for the $3 \mathrm{~d} \mathrm{M}^{3+}$ ions enable the first analysis of the trend across the $3 \mathrm{~d}$ transition series in $\Delta \mathrm{G}_{\mathrm{hyd}}\left(\mathrm{M}^{3+}\right)$ which should be of considerable chemical interest.

\section{METHODS}

Conventions used. The thermochemical cycle relevant to the problem can be written as in Figure 1. The calculated values refer to the standard states applied in the experimental data from which they were derived, which include unity activities ( $1 \mathrm{M}$ concentrations), $\mathrm{T}=298.15 \mathrm{~K}$, and 1 atm pressure. The gray color covers the three micro-processes involved in the experimentally determined operational reduction potential, which includes the chemical potential of the electron in the electrode $M$, the surface potential of water $\chi^{\mathrm{S}}$, and the hydration free energy of $\mathrm{H}_{2}, \Delta \mathrm{G}_{\text {hyd }}\left(\mathrm{H}_{2}\right)$, which, as discussed below, is of the order of $\sim 2 \mathrm{~kJ} / \mathrm{mol}$. All these terms are components of the experimentally observable standard potential, $\mathrm{E}_{\mathrm{SHE}}^{0}(\mathrm{abs})=-\Delta \mathrm{G}_{\mathrm{el}}(\mathrm{SHE}) / z F$, where $F$ is the Faraday constant and $z$ is the transferred charge.

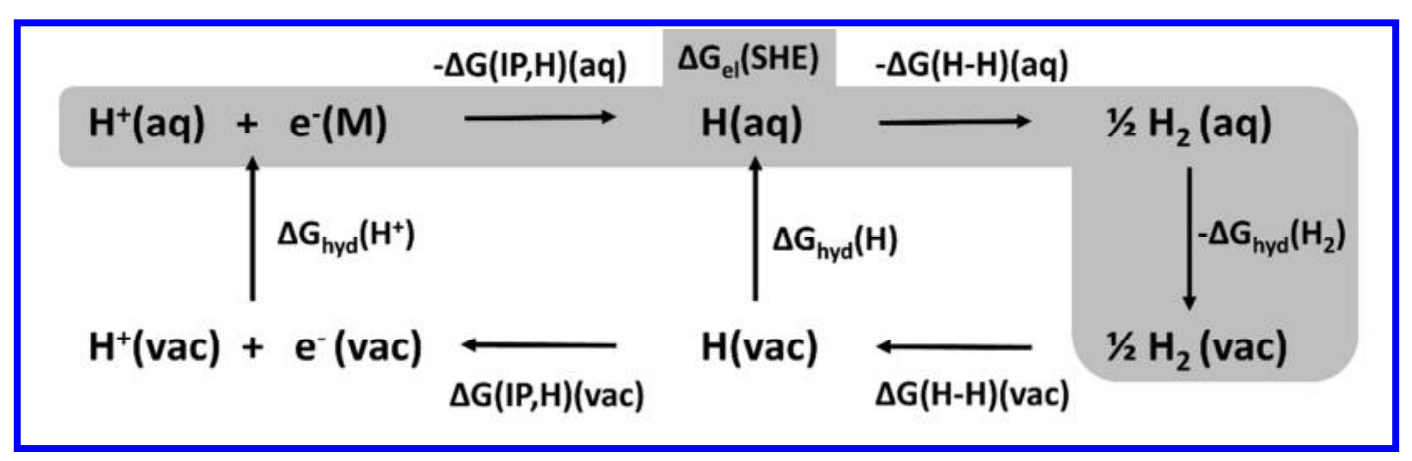

Figure 1. Thermochemical cycle for calculating the absolute potential of the standard hydrogen electrode. The experimentally measured electrode potential $\Delta \mathrm{G}_{\mathrm{el}}(\mathrm{SHE})$ consists of the processes marked in gray color and includes the surface potential of the solvent (water), $\chi^{\mathrm{S}}$. 
As discussed notably by $\operatorname{Trasatti}^{19}$, one can compute $\mathrm{E}_{\text {SHE }}^{0}(\mathrm{abs})$ (and thus $\Delta \mathrm{G}_{\mathrm{el}}(\mathrm{SHE})$ ) from the three processes of the bottom left of Figure 1. The two vacuum terms $1 / 2 \Delta \mathrm{G}(\mathrm{H}-\mathrm{H})(\mathrm{vac})$ and $\Delta \mathrm{G}(\mathrm{IP}, \mathrm{H})(\mathrm{vac})$ are accurately known; they represent the free energy of atomization of $\mathrm{H}_{2}$ and ionization of $\mathrm{H}$ in vacuum. $\Delta \mathrm{G}(\mathrm{H}-\mathrm{H})(\mathrm{vac})$ is the bond dissociation free energy of $\mathrm{H}_{2}$ and equals 406 $\mathrm{kJ} / \mathrm{mol}$; it consists of $\mathrm{D}_{0}(\mathrm{H}-\mathrm{H})=436 \mathrm{~kJ} / \mathrm{mol}-30 \mathrm{~kJ} / \mathrm{mol} \mathrm{T} \Delta \mathrm{S}$ at $298.15 \mathrm{~K}$ as given directly by tabulated formation free energies and enthalpies. $\Delta \mathrm{G}(\mathrm{IP}, \mathrm{H})(\mathrm{vac})$ is equal is to the ionization potential of hydrogen $(1312 \mathrm{~kJ} / \mathrm{mol})$ plus a small $1.8 \mathrm{~kJ} / \mathrm{mol}$ of $\mathrm{T} \Delta \mathrm{S}$ as estimated from the Sackur-Tetrode equation $^{23}$. The remaining free energy, $\Delta \mathrm{G}_{\mathrm{hyd}}\left(\mathrm{H}^{+}\right)$, is the hydration free energy of the proton. As can be seen from Figure 1, it involves a phase change from air to water and thus includes $\chi^{S}$. Most discrepancy between values used in the literature relate to this term, which consequently also affects calculation of $\Delta \mathrm{G}_{\mathrm{el}}(\mathrm{SHE})^{24}$.

A long list of $\Delta \mathrm{G}_{\mathrm{hyd}}\left(\mathrm{H}^{+}\right)$reported by different authors was compiled by Rosseinsky, showing well the heterogeneity in these early numbers ${ }^{14}$; they tend to converge on $-1090 \pm 5 \mathrm{~kJ} / \mathrm{mol} \mathrm{kJ} / \mathrm{mol}$. The modern consensus value of $\Delta \mathrm{G}_{\mathrm{hyd}}\left(\mathrm{H}^{+}\right)$is probably $-1100 \pm 5 \mathrm{~kJ} / \mathrm{mol}$ : Zhan and Dixon reported $1098 \mathrm{~kJ} / \mathrm{mol}^{25}$ whereas Tissandier et al. reported $-1104.5 \mathrm{~kJ} / \mathrm{mol}^{21}$. These values importantly do not include the surface potential $\chi^{\mathrm{S}}$ as they result from interpolation of quantum chemical cluster calculations. Most of the $\sim 10 \mathrm{~kJ} / \mathrm{mol}$ difference in the values near $-1090 \mathrm{~kJ} / \mathrm{mol}$ and $-1100 \mathrm{~kJ} / \mathrm{mol}$ is thus due to $\chi^{\mathrm{S}}$. The latter are the chemical free energies of hydration whereas the former represent the chemical potential of the proton once it is in water. The standard chemical potential of the proton in water was calculated by Trasatti ${ }^{19}$ and Farrell and McTigue ${ }^{26}$ to be $-1088 \mathrm{~kJ} / \mathrm{mol}$. Fawcett ${ }^{24}$ derived the value $-1088 \mathrm{~kJ} / \mathrm{mol}$ from the work function of mercury, and another value of $-1091 \mathrm{~kJ} / \mathrm{mol}$ by reassessment of the data of Randles ${ }^{27}$. Thus this number has an accuracy of $\pm 3 \mathrm{~kJ} / \mathrm{mol}$.

If one uses $-1100 \mathrm{~kJ} / \mathrm{mol}$ directly with the thermochemical cycle and the above stated numbers, one obtains $\Delta \mathrm{G}_{\mathrm{el}}(\mathrm{SHE})=-4.32 \mathrm{~V}$. This value corresponds to a SHE potential whose value was determined without the surface potential of water. The surface potential was estimated by Trasatti to be $+0.13 \mathrm{~V}^{19}$, by Farrell and McTigue to be $+0.025 \mathrm{~V}^{26}$, and by Krishtalik to be $+0.14 \mathrm{~V}^{28}$. Parfenyuk estimated a consensus value of $+0.10 \mathrm{~V}$ from a survey of data ${ }^{29}$, which agrees well with the $\sim 10 \mathrm{~kJ} / \mathrm{mol}$ discussed above. The consensus positive value of the surface potential is physically meaningful and probably accurate to within $0.05 \mathrm{~V}$. The positive value implies that water oxygen atoms tend to be overrepresented at the surface in order to maximize the water-water hydrogen bond interactions; this produces a potential at the surface due to the non-random alignment of dipoles. The present work uses 
the $+0.13 \mathrm{~V}$ by Trasatti as it is close to the density of consensus values and was calculated directly from the chemical potential of the proton. The uncertainty in this number makes the total uncertainty of the calculated values of the order of $0.05 \mathrm{~V}$. Including the $+0.13 \mathrm{~V}$ produces the commonly defined absolute electrode potential of $4.45 \mathrm{~V}$ (note that $-1089 \mathrm{~kJ} / \mathrm{mol}$ is the value of $\Delta \mathrm{G}_{\mathrm{hyd}}\left(\mathrm{H}^{+}\right)$that gives exactly $4.44 \mathrm{~V})$. These points are discussed in detail by Farrell and McTigue, who computed the numbers as $4.31 \mathrm{~V}$ and $4.44 \mathrm{~V}^{26}$. Each scale has an estimated error of $\pm 0.05 \mathrm{~V}$ associated with the thermochemical cycle calculations dominated by the uncetrainty in the surface potential, which translates into $5 \mathrm{~kJ} / \mathrm{mol}$ for the tabulated values of $\Delta \mathrm{G}_{\text {hyd }}\left(\mathrm{M}^{\mathrm{n}+}\right)$ below. To this uncertainty, one should add the experimental uncertainty in the actual measurement of one value of $\Delta \mathrm{G}_{\mathrm{hyd}}\left(\mathrm{M}^{\mathrm{n}+}\right)$, which is probably largest for the trivalent ions, assuming that errors scale monotonously with the magnitude of $\Delta \mathrm{G}_{\text {hyd }}$. An estimate of the overall error in the tabulated values is thus $\pm 10 \mathrm{~kJ} / \mathrm{mol}$.

Now we discuss the metal ion potentials of interest to the present work. Using a Born-Haber cycle one can calculate the standard half potential for a metal of any given charge, i.e. the process

$$
\mathrm{M}^{\mathrm{n}+}+n \mathrm{e}^{-} \rightarrow \mathrm{M}
$$

as $^{19}$ :

$$
\mathrm{E}_{1 / 2}^{0}\left(\mathrm{M}^{\mathrm{n}+} / \mathrm{M}\right)=\left(\Delta \mathrm{G}_{\mathrm{at}}{ }^{0}+\Delta \mathrm{G}\left(\mathrm{IP}_{\mathrm{n}}, \mathrm{M}\right)+\Delta \mathrm{G}_{\mathrm{hyd}}\left(\mathrm{M}^{\mathrm{n}+}\right)\right) / n F
$$

where $\Delta \mathrm{G}_{\mathrm{at}}{ }^{0}$ is the standard atomization free energy of the metal and $\Delta \mathrm{G}\left(\mathrm{IP}_{\mathrm{n}}, \mathrm{M}\right)$ is the sum of ionization free energies required to bring $\mathrm{M}$ to $\mathrm{M}^{\mathrm{n}+}$ (i.e. if $n=2$, it is the sum of the first and second ionization free energies).

The definition of the hydration free energy $\Delta \mathrm{G}_{\mathrm{hyd}}\left(\mathrm{M}^{\mathrm{n}+}\right)$ again depends on whether one includes the surface potential or not. However, when interested in the standard half potentials $\mathrm{E}_{1 / 2}{ }^{0}\left(\mathrm{M}^{3+} / \mathrm{M}^{2+}\right)$, we may write:

$$
\begin{aligned}
& \mathrm{E}_{1 / 2}^{0}\left(\mathrm{M}^{3+} / \mathrm{M}^{2+}\right)=\mathrm{E}_{1 / 2}^{0}\left(\mathrm{M}^{3+} / \mathrm{M}\right)-\mathrm{E}_{1 / 2}^{0}\left(\mathrm{M}^{2+} / \mathrm{M}\right) \\
& =\left(\Delta \mathrm{G}\left(\mathrm{IP}_{32}, \mathrm{M}\right)+\Delta \mathrm{G}_{\mathrm{hyd}}\left(\mathrm{M}^{3+}\right)-\Delta \mathrm{G}_{\mathrm{hyd}}\left(\mathrm{M}^{2+}\right)\right) / n \mathrm{~F}
\end{aligned}
$$

Here, $\Delta \mathrm{G}\left(\mathrm{IP}_{32}, \mathrm{M}\right)$ is the third ionization potential of $\mathrm{M}$, which is available at very high accuracy in the NIST database. In other words, when calculating the standard half potential between two ions, the atomization free energy and the surface potential cancel out to leave a simple cycle that is calculated with the same accuracy as the accuracy of the difference in the experimental hydration free energies, which is similar to or smaller than the accuracy of the experimental $\Delta \mathrm{G}_{\mathrm{hyd}}\left(\mathrm{M}^{3+}\right)$, which is by far the 
largest of the two numbers. When using the thermochemical cycle in Figure 1, the SHE $=+4.44 \mathrm{~V}$ should be used because the standard half potentials refer to this value of SHE, which includes the surface potential.

To summarize the above, this work considers processes involving the $\mathrm{E}_{1 / 2}^{0}$ of the $\mathrm{M}^{3+} / \mathrm{M}^{2+}$ redox pairs and uses the consensus values $\mathrm{E}_{\mathrm{SHE}}^{0}(\mathrm{abs})=4.44 \mathrm{~V}$ and $\Delta \mathrm{G}_{\mathrm{hyd}}\left(\mathrm{H}^{+}\right)=-1100 \mathrm{~kJ} / \mathrm{mol}$. Values of $\mathrm{E}_{1 / 2}{ }^{0}$ were taken from the electrochemical series reported in the CRC Handbook ${ }^{30}$, and from Bratsch for $\mathrm{E}_{1 / 2}^{0}\left(\mathrm{Ni}^{3+} / \mathrm{Ni}^{2+}\right)=+2.3 \mathrm{~V}^{31}$ (data shown in Supporting Information, Table S1). The $\Delta \mathrm{G}_{\text {hyd }}$ were derived from the values tabulated by Marcus ${ }^{10,11}$. These assume the TATB approximation and $\Delta \mathrm{G}_{\text {hyd }}\left(\mathrm{H}^{+}\right)$of $-1056 \mathrm{~kJ} / \mathrm{mol}$, and have thus been corrected to the new consensus value of $\Delta \mathrm{G}_{\mathrm{hyd}}\left(\mathrm{H}^{+}\right)=-1100 \mathrm{~kJ} / \mathrm{mol}$ before use in the cycle. As explained above, one can convert between the thermochemical and operational electrode potentials by using $4.31 \mathrm{~V}$ instead of $4.44 \mathrm{~V}$; this is done by making the tabulated $\Delta \mathrm{G}_{\text {hyd }}$ values below $13 \mathrm{~kJ} / \mathrm{mol}$ smaller. Several other choices can be made for $\Delta \mathrm{G}_{\mathrm{hyd}}\left(\mathrm{H}^{+}\right)$and can easily be used to calculate revised $\Delta \mathrm{G}_{\text {hyd }}$ from the data presented here. Notably, if the interest is in conventional free energies of hydration $\left(\Delta \mathrm{G}_{\mathrm{hyd}}\left(\mathrm{H}^{+}\right)=0\right)$, the value $-1100 n \mathrm{~kJ} / \mathrm{mol}$ should be subtracted from the tabulated data in Tables 1 and 2.

Note on the hydration free energy of $\mathbf{H}_{2}$. A small note on the involvement of the hydration of $\mathrm{H}_{2}$ during measurement of the operational potential: The hydration free energy of $\mathrm{H}_{2}$ is probably of the order of $2 \mathrm{~kJ} / \mathrm{mol}$, which corresponds to an effect on SHE of $0.01 \mathrm{~V}$, and thus this process has little effect even when computing "absolute" potentials. This free energy should resemble the cavitation free energy of water ${ }^{32}$ for a cavity with a size of perhaps $3 \AA$ from the center of mass of $\mathrm{H}_{2}$ to nearest oxygen neighbors ${ }^{33}$, or a thermal radius of the cavity of $\sim 2 \AA^{34}$. However, this term does not affect the standard half potentials computed according to Equation (3), and thus does not affect this work's results.

Note on Brønsted acidity of $\mathbf{M}^{3+}(\mathbf{a q})$. The thermochemical cycle may involve deprotonation of a water associated with the first coordination shell of the $\mathrm{M}^{3+}$ ions, but not the $\mathrm{M}^{2+}$ ions, due to the Brønsted acidity of the aqua complexes of the $\mathrm{M}^{3+}$ ions. Because the thermochemical cycle is based on the species in solution that give rise to the potential and hydration free energy of $\mathrm{M}^{3+}$, this does not affect the accuracy of the tabulated data but it means that the data refer to the real species during measurement, and not necessarily to the same hydrated state of the $\mathrm{M}^{2+}$ and $\mathrm{M}^{3+}$ ions. For example, $\mathrm{Co}^{3+}$ is well-known to be unstable and is reduced to $\mathrm{Co}^{2+}$ unless in very strong acid, and one can 
therefore discuss whether the tabulated potentials and hydration free energies of such cases reflect a single species in solution or not.
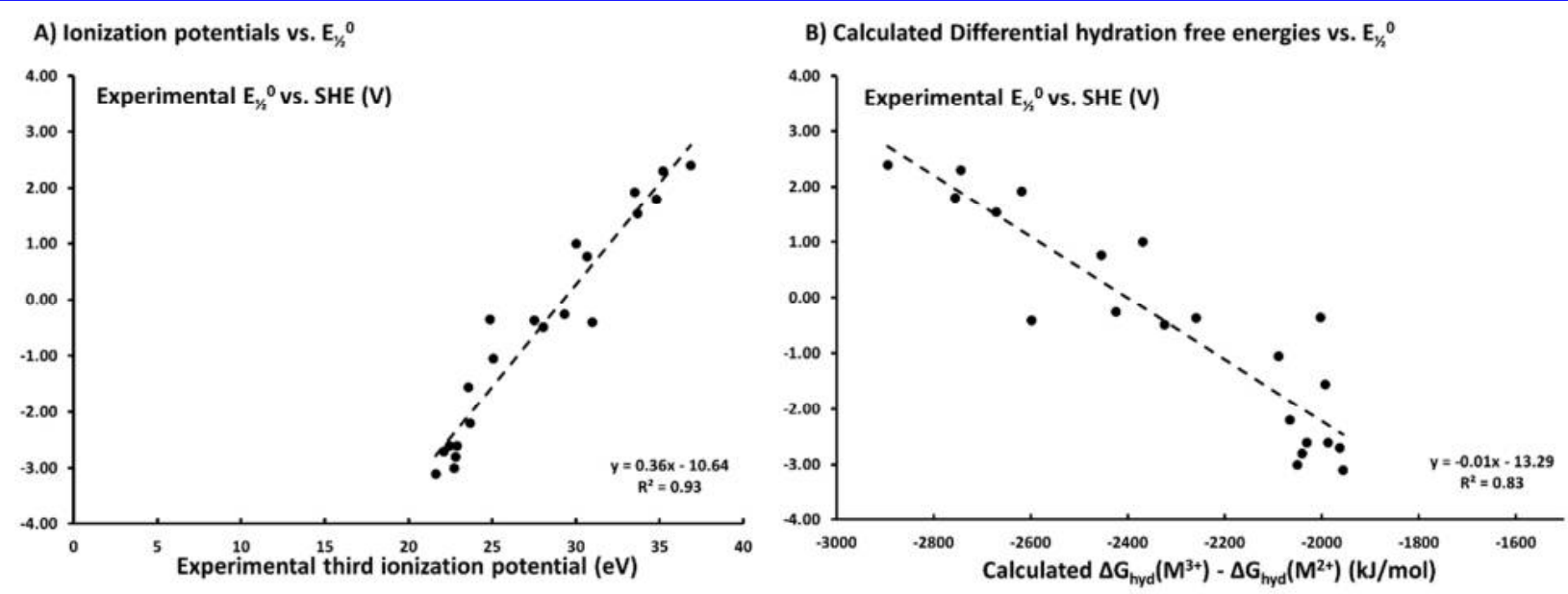

C) Calculated vs. Experimental $\mathrm{E}_{\%}{ }^{0}\left(\mathrm{M}^{3+}+\mathrm{e}^{-} \rightarrow \mathrm{M}^{2+}\right)$ including $\mathrm{Cr}^{3+} / \mathrm{Cr}^{2+}$

D) Calculated vs. Experimental $\mathrm{E}_{\mathrm{y}}{ }^{0}\left(\mathrm{M}^{3+}+\mathrm{e}^{-} \rightarrow \mathrm{M}^{2+}\right)$ excluding $\mathrm{Cr}^{3+} / \mathrm{Cr}^{2+}$
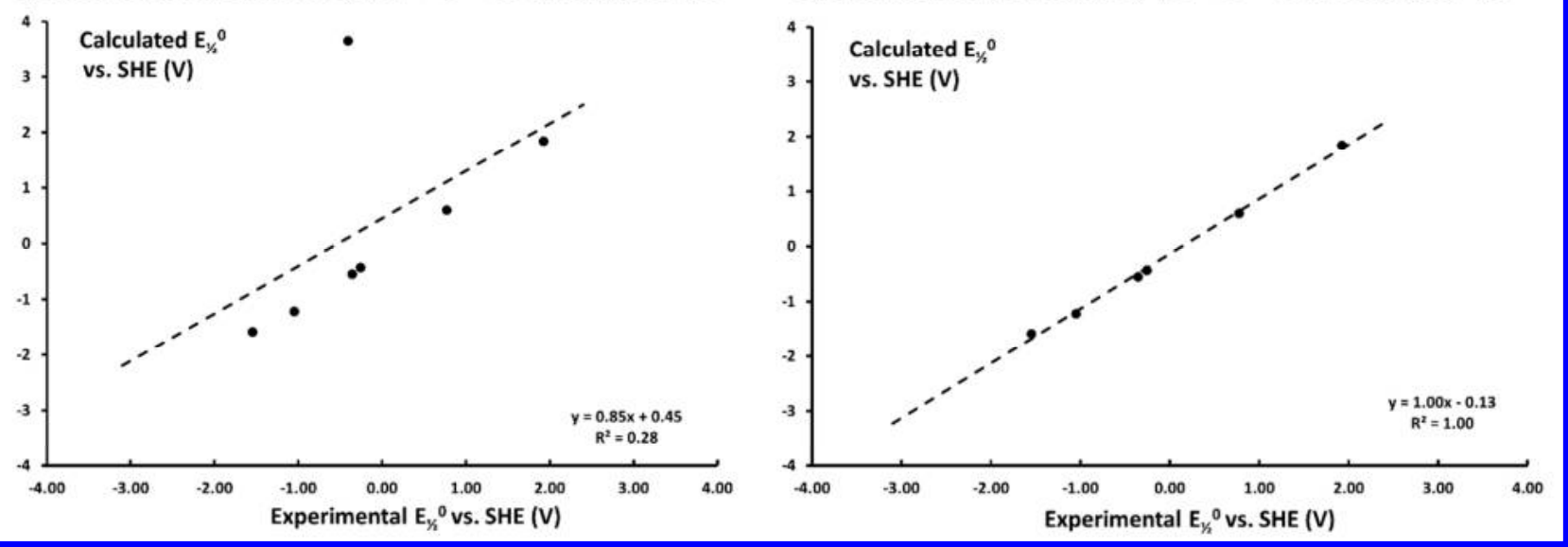

Figure 2. A) Third ionization potential plotted vs. standard half potentials. B) The difference in calculated hydration free energies of trivalent and divalent metal ions plotted against standard half potentials. C) Experimental vs. calculated standard half potentials using the corrected Marcus data for hydration free energies. D) Same as $\mathrm{C}$, but excluding the $\mathrm{Cr}^{3+} / \mathrm{Cr}^{2+}$ potential $(\mathrm{MAD}=0.11 \mathrm{~V})$. 


\section{RESULTS AND DISCUSSION}

Figure $2 \mathrm{~A}$ shows the experimental third IP of the metals vs. the experimental $\mathrm{E}_{1 / 2}^{0}\left(\mathrm{M}^{3+} / \mathrm{M}^{2+}\right)$. The correlation is very strong $\left(\mathrm{R}^{2}=0.93\right)$, showing that vacuum IPs largely explain the magnitude of the half potentials in solution, but not perfectly; the scatter is caused by the neglect of the difference $\Delta \mathrm{G}_{\text {hyd }}\left(\mathrm{M}^{3+}\right)-\Delta \mathrm{G}_{\text {hyd }}\left(\mathrm{M}^{2+}\right)$, which varies for the redox couples. Figure 2B correspondingly shows the relationship between this difference $\Delta \mathrm{G}_{\text {hyd }}\left(\mathrm{M}^{3+}\right)-\Delta \mathrm{G}_{\mathrm{hyd}}\left(\mathrm{M}^{2+}\right)$ and the experimental $\mathrm{E}_{1 / 2}^{0}\left(\mathrm{M}^{3+} / \mathrm{M}^{2+}\right)$. Also for this property, the correlation is strong $\left(\mathrm{R}^{2}=0.83\right)$. One can conclude from this decomposition in Figure 2A and 2B that both the differential hydration free energy of the redox couple and the vacuum IP contribute approximately similarly to the overall observed standard half potentials, with slightly more importance given to the IPs.

Figure 2C and Figure 2D show the relationship between experimental $\mathrm{E}_{\frac{1}{2} / 2}^{0}$ and those computed from the thermochemical cycle using the values by Marcus corrected by (1100-1056)n $\mathrm{kJ} / \mathrm{mol}$ where data are available for both $\Delta \mathrm{G}_{\mathrm{hyd}}\left(\mathrm{M}^{3+}\right)$ and $\Delta \mathrm{G}_{\mathrm{hyd}}\left(\mathrm{M}^{2+}\right)(\mathrm{Co}, \mathrm{Cr}, \mathrm{Eu}, \mathrm{Fe}, \mathrm{Sm}, \mathrm{V}, \mathrm{Yb})$. Except for $\mathrm{Cr}^{3+} / \mathrm{Cr}^{2+}$, the thermochemical cycle calculations very accurately reproduce the experimental $\mathrm{E}_{1 / 2}^{0}\left(\mathrm{R}^{2}=1.00\right.$, mean average deviation $\left.(\mathrm{MAD})=0.11 \mathrm{~V}\right)$. The correlation coefficient shows that the thermochemical cycle is complete and sufficient for the purpose of calculation, and is thus used below. The MAD between experimental and calculated half potentials further confirm that the applied procedure has an accuracy of $\sim 10 \mathrm{~kJ} / \mathrm{mol}$.

From Figure 2C and Figure 2D one can conclude that the tabulated $\Delta \mathrm{G}_{\text {hyd }}$ for $\mathrm{Cr}^{3+}$ or $\mathrm{Cr}^{2+}$ or both is wrong. As shown below, the source of the error in $\mathrm{Cr}^{3+} / \mathrm{Cr}^{2+}$ half potential originates from $\Delta \mathrm{G}_{\mathrm{hyd}}\left(\mathrm{Cr}^{3+}\right)=-4010 \mathrm{~kJ} / \mathrm{mol}$ as reported by Marcus, which is too small. For comparison, Gomer and Tryson reported $-4367 \mathrm{~kJ} / \mathrm{mol}^{20}$, and Noyes reported $-4339 \mathrm{~kJ} / \mathrm{mol}^{13}$. Using the thermochemical cycle and the corrected value of $\Delta \mathrm{G}_{\mathrm{hyd}}\left(\mathrm{Cr}^{2+}\right)$ of $-1938 \mathrm{~kJ} / \mathrm{mol}$, a new value of $\Delta \mathrm{G}_{\mathrm{hyd}}\left(\mathrm{Cr}^{3+}\right)=-4536 \mathrm{~kJ} / \mathrm{mol}$ is obtained (Table 1). This value is essentially the same as that reported by Fawcett ${ }^{15},-4531 \mathrm{~kJ} / \mathrm{mol}$, once the conventional value has been converted for comparison by $\Delta \mathrm{G}_{\mathrm{hyd}}\left(\mathrm{H}^{+}\right)=-1100 \mathrm{~kJ} / \mathrm{mol}$. 


\section{Table 1. Free Energies of Hydration for Trivalent Metal Ions (kJ/mol).}

$$
\Delta \mathrm{G}_{\mathrm{hyd}}\left(\mathrm{H}^{+}\right)=-1100 \mathrm{~kJ} / \mathrm{mol} \text { and } \mathrm{SHE}=4.44 \mathrm{~V}^{\mathrm{a}}
$$

\begin{tabular}{|c|c|c|c|c|c|c|}
\hline & Marcus $^{10,11}$ & $\begin{array}{l}\text { Marcus, } \\
\text { corrected }\end{array}$ & Noyes $^{13}$ & Fawcett $^{15, b}$ & $\begin{array}{l}\text { This } \\
\text { work }\end{array}$ & Notes \\
\hline $\mathrm{Ag}^{3+}$ & N/A & N/A & N/A & N/A & -4683 & from $\mathrm{E}_{32}$ and $\Delta \mathrm{G}_{\mathrm{hyd}}\left(\mathrm{M}^{2+}\right.$, this work $)$ \\
\hline $\mathrm{Al}^{3+}$ & -4525 & -4663 & N/A & -4662 & -4657 & Marcus corrected value \\
\hline $\mathrm{Au}^{3+}$ & -4420 & -4558 & N/A & $\mathrm{N} / \mathrm{A}$ & -4324 & from $\mathrm{E}_{32}$ and $\Delta \mathrm{G}_{\mathrm{hyd}}\left(\mathrm{M}^{2+}\right.$, this work $)$ \\
\hline $\mathrm{Bi}^{3+}$ & -3480 & -3618 & N/A & N/A & -3612 & Marcus corrected value \\
\hline $\mathrm{Ce}^{3+}$ & -3200 & -3338 & $\mathrm{~N} / \mathrm{A}$ & N/A & -3332 & Marcus corrected value \\
\hline $\mathrm{Co}^{3+}$ & -4495 & -4633 & $\mathrm{~N} / \mathrm{A}$ & N/A & -4622 & from $\mathrm{E}_{32}$ and $\Delta \mathrm{G}_{\mathrm{hyd}}\left(\mathrm{M}^{2+}\right.$, Marcus, corrected $)$ \\
\hline $\mathrm{Cr}^{3+}$ & -4010 & -4148 & -4339 & -4531 & -4536 & from $\mathrm{E}_{32}$ and $\Delta \mathrm{G}_{\mathrm{hyd}}\left(\mathrm{M}^{2+}\right.$, Marcus, corrected $)$ \\
\hline $\mathrm{Cu}^{3+}$ & N/A & $\mathrm{N} / \mathrm{A}$ & $\mathrm{N} / \mathrm{A}$ & $\mathrm{N} / \mathrm{A}$ & $\underline{-4979}$ & from $\mathrm{E}_{32}$ and $\Delta \mathrm{G}_{\mathrm{hyd}}\left(\mathrm{M}^{2+}\right.$, this work $)$ \\
\hline $\mathrm{Dy}^{3+}$ & -3425 & -3563 & N/A & N/A & -3557 & Marcus corrected value \\
\hline $\mathrm{Er}^{3+}$ & -3495 & -3633 & $\mathrm{~N} / \mathrm{A}$ & N/A & -3627 & Marcus corrected value \\
\hline $\mathrm{Eu}^{3+}$ & -3360 & -3498 & -3527 & N/A & -3476 & from $\mathrm{E}_{32}$ and $\Delta \mathrm{G}_{\mathrm{hyd}}\left(\mathrm{M}^{2+}\right.$, Marcus, corrected $)$ \\
\hline $\mathrm{Fe}^{3+}$ & -4265 & -4403 & -4335 & -4416 & -4383 & from $\mathrm{E}_{32}$ and $\Delta \mathrm{G}_{\mathrm{hyd}}\left(\mathrm{M}^{2+}\right.$, Marcus, corrected $)$ \\
\hline $\mathrm{Ho}^{3+}$ & -3470 & -3608 & N/A & N/A & -3602 & Marcus corrected value \\
\hline $\mathrm{In}^{3+}$ & -3980 & -4118 & -4100 & -4121 & -4112 & Marcus corrected value \\
\hline $\mathrm{La}^{3+}$ & -3145 & -3283 & $\mathrm{~N} / \mathrm{A}$ & $\mathrm{N} / \mathrm{A}$ & -3277 & Marcus corrected value \\
\hline $\mathrm{Mn}^{3+}$ & N/A & N/A & N/A & N/A & $\underline{-4520}$ & from $\mathrm{E}_{32}$ and $\Delta \mathrm{G}_{\mathrm{hyd}}\left(\mathrm{M}^{2+}\right.$, Marcus, corrected $)$ \\
\hline $\mathrm{Nd}^{3+}$ & -3280 & -3418 & N/A & N/A & $\overline{-3412}$ & Marcus corrected value \\
\hline $\mathrm{Ni}^{3+}$ & N/A & $\mathrm{N} / \mathrm{A}$ & $\mathrm{N} / \mathrm{A}$ & N/A & $\underline{-4813}$ & from $\mathrm{E}_{32}$ and $\Delta \mathrm{G}_{\mathrm{hyd}}\left(\mathrm{M}^{2+}\right.$, Marcus, corrected $)$ \\
\hline $\mathrm{Pm}^{3+}$ & -3250 & -3388 & N/A & N/A & -3382 & Marcus corrected value \\
\hline $\operatorname{Pr}^{3+}$ & -3245 & -3383 & $\mathrm{~N} / \mathrm{A}$ & N/A & -3377 & Marcus corrected value \\
\hline $\mathrm{Pu}^{3+}$ & -3235 & -3373 & $\mathrm{~N} / \mathrm{A}$ & N/A & -3367 & Marcus corrected value \\
\hline $\mathrm{Sc}^{3+}$ & -3795 & -3933 & $\mathrm{~N} / \mathrm{A}$ & -3933 & -3927 & Marcus corrected value \\
\hline $\mathrm{Sm}^{3+}$ & -3325 & -3463 & $\mathrm{~N} / \mathrm{A}$ & N/A & -3456 & from $\mathrm{E}_{32}$ and $\Delta \mathrm{G}_{\mathrm{hyd}}\left(\mathrm{M}^{2+}\right.$, Marcus, corrected $)$ \\
\hline $\mathrm{Ti}^{3+}$ & -4015 & -4153 & -4046 & N/A & -4147 & Marcus corrected value \\
\hline $\mathrm{Tm}^{3+}$ & -3515 & -3653 & $\mathrm{~N} / \mathrm{A}$ & N/A & -3647 & Marcus corrected value \\
\hline $\mathrm{U}^{3+}$ & -3205 & -3343 & $\mathrm{~N} / \mathrm{A}$ & N/A & -3337 & Marcus corrected value \\
\hline $\mathrm{V}^{3+}$ & -4220 & -4358 & N/A & N/A & -4338 & from $\mathrm{E}_{32}$ and $\Delta \mathrm{G}_{\mathrm{hyd}}\left(\mathrm{M}^{2+}\right.$, Marcus, corrected $)$ \\
\hline $\mathrm{Yb}^{3+}$ & -3570 & -3708 & $\mathrm{~N} / \mathrm{A}$ & $\mathrm{N} / \mathrm{A}$ & -3688 & from $\mathrm{E}_{32}$ and $\Delta \mathrm{G}_{\mathrm{hyd}}\left(\mathrm{M}^{2+}\right.$, Marcus, corrected $)$ \\
\hline
\end{tabular}

${ }^{a}$ Numbers where previous data are unavailable in the compilations by Noyes, Marcus, and Fawcett are marked bold and underlined; numbers changed by more than $20 \mathrm{~kJ} / \mathrm{mol}$ are marked in bold. ${ }^{\mathrm{b}}$ Values reported by Fawcett were converted from conventional data using $\Delta \mathrm{G}_{\mathrm{hyd}}\left(\mathrm{H}^{+}\right)=-1100 \mathrm{~kJ} / \mathrm{mol}$. 
Table 2. Free Energies of Hydration for Divalent Metal Ions (kJ/mol). $\Delta \mathrm{G}_{\mathrm{hyd}}\left(\mathrm{H}^{+}\right)=-1100 \mathrm{~kJ} / \mathrm{mol}$ and $\mathrm{SHE}=4.44 \mathrm{~V}^{\mathrm{a}}$

\begin{tabular}{|c|c|c|c|c|c|c|}
\hline & Marcus $^{10,11}$ & $\begin{array}{l}\text { Marcus, } \\
\text { corrected }\end{array}$ & Noyes $^{13}$ & Fawcett $^{15, b}$ & $\begin{array}{l}\text { This } \\
\text { work }\end{array}$ & Notes \\
\hline $\mathrm{Ag}^{2+}$ & -1865 & -1953 & N/A & $\mathrm{N} / \mathrm{A}$ & -1953 & Marcus corrected value \\
\hline $\mathrm{Au}^{2+}$ & N/A & $\mathrm{N} / \mathrm{A}$ & N/A & $\mathrm{N} / \mathrm{A}$ & -1954 & from $\mathrm{E}_{21}$ and $\Delta \mathrm{G}_{\mathrm{hyd}}\left(\mathrm{M}^{+}\right.$, Noyes $)$ \\
\hline $\mathrm{Ba}^{2+}$ & -1250 & -1338 & -1314 & -1343 & $\overline{-1338}$ & Marcus corrected value \\
\hline $\mathrm{Be}^{2+}$ & -2395 & -2483 & -2436 & -2489 & -2483 & Marcus corrected value \\
\hline $\mathrm{Ca}^{2+}$ & -1505 & -1593 & -1588 & -1599 & -1593 & Marcus corrected value \\
\hline $\mathrm{Cd}^{2+}$ & -1755 & -1843 & -1795 & -1820 & -1843 & Marcus corrected value \\
\hline $\mathrm{Co}^{2+}$ & -1915 & -2003 & N/A & -2008 & -2003 & Marcus corrected value \\
\hline $\mathrm{Cr}^{2+}$ & -1850 & -1938 & -2013 & -1924 & -1938 & Marcus corrected value \\
\hline $\mathrm{Cu}^{2+}$ & -2010 & -2098 & $\mathrm{~N} / \mathrm{A}$ & -2100 & -2086 & from $\mathrm{E}_{21}$ and $\Delta \mathrm{G}_{\mathrm{hyd}}\left(\mathrm{M}^{+}\right.$, Marcus, corrected $)$ \\
\hline $\mathrm{Dy}^{2+}$ & N/A & N/A & N/A & N/A & $\underline{-1526}$ & from $\mathrm{E}_{32}$ and $\Delta \mathrm{G}_{\mathrm{hyd}}\left(\mathrm{M}^{3+}\right.$, Marcus, corrected $)$ \\
\hline $\mathrm{Er}^{2+}$ & N/A & N/A & N/A & N/A & $\underline{-1576}$ & from $\mathrm{E}_{32}$ and $\Delta \mathrm{G}_{\mathrm{hyd}}\left(\mathrm{M}^{3+}\right.$, Marcus, corrected $)$ \\
\hline $\mathrm{Eu}^{2+}$ & -1385 & -1473 & $\mathrm{~N} / \mathrm{A}$ & $\mathrm{N} / \mathrm{A}$ & $\overline{-1473}$ & Marcus corrected value \\
\hline $\mathrm{Fe}^{2+}$ & -1840 & -1928 & -1890 & -1949 & -1928 & Marcus corrected value \\
\hline $\mathrm{Hg}^{2+}$ & -1760 & -1848 & -1820 & -1850 & -1848 & Marcus corrected value \\
\hline $\mathrm{Ho}^{2+}$ & $\mathrm{N} / \mathrm{A}$ & $\mathrm{N} / \mathrm{A}$ & $\mathrm{N} / \mathrm{A}$ & N/A & $\underline{-1561}$ & from $\mathrm{E}_{32}$ and $\Delta \mathrm{G}_{\mathrm{hyd}}\left(\mathrm{M}^{3+}\right.$, Marcus, corrected $)$ \\
\hline $\operatorname{In}^{2+}$ & N/A & N/A & N/A & N/A & $\underline{-1787}$ & from $\mathrm{E}_{32}$ and $\Delta \mathrm{G}_{\mathrm{hyd}}\left(\mathrm{M}^{3+}\right.$, Marcus, corrected $)$ \\
\hline $\mathrm{Mg}^{2+}$ & -1830 & -1918 & -1900 & -1922 & -1918 & Marcus corrected value \\
\hline $\mathrm{Mn}^{2+}$ & -1760 & -1848 & N/A & -1859 & -1848 & Marcus corrected value \\
\hline $\mathrm{Nd}^{2+}$ & N/A & $\mathrm{N} / \mathrm{A}$ & N/A & $\mathrm{N} / \mathrm{A}$ & $\underline{-1448}$ & from $\mathrm{E}_{32}$ and $\Delta \mathrm{G}_{\mathrm{hyd}}\left(\mathrm{M}^{3+}\right.$, Marcus, corrected $)$ \\
\hline $\mathrm{Ni}^{2+}$ & -1980 & -2068 & -2062 & -2087 & -2068 & Marcus corrected value \\
\hline $\mathrm{Pb}^{2+}$ & -1425 & -1513 & -1492 & -1518 & -1513 & Marcus corrected value \\
\hline $\mathrm{Pd}^{2+}$ & -1910 & -1998 & -2397 & N/A & -1998 & Marcus corrected value \\
\hline $\mathrm{Pm}^{2+}$ & N/A & $\mathrm{N} / \mathrm{A}$ & N/A & N/A & -1394 & from $\mathrm{E}_{32}$ and $\Delta \mathrm{G}_{\mathrm{hyd}}\left(\mathrm{M}^{3+}\right.$, Marcus, corrected $)$ \\
\hline $\operatorname{Pr}^{2+}$ & N/A & N/A & N/A & N/A & $\underline{-1420}$ & from $\mathrm{E}_{32}$ and $\Delta \mathrm{G}_{\mathrm{hyd}}\left(\mathrm{M}^{3+}\right.$, Marcus, corrected $)$ \\
\hline $\mathrm{Pt}^{2+}$ & -1960 & -2048 & N/A & N/A & -2048 & Marcus corrected value \\
\hline $\mathrm{Ra}^{2+}$ & -1250 & -1338 & -1280 & N/A & -1338 & Marcus corrected value \\
\hline $\mathrm{Sm}^{2+}$ & -1375 & -1463 & N/A & N/A & -1463 & Marcus corrected value \\
\hline $\mathrm{Sn}^{2+}$ & -1490 & -1578 & -1554 & -1581 & -1578 & Marcus corrected value \\
\hline $\mathrm{Sr}^{2+}$ & -1380 & -1468 & -1421 & -1470 & -1468 & Marcus corrected value \\
\hline $\mathrm{Ti}^{2+}$ & N/A & N/A & -1782 & N/A & -1887 & from $\mathrm{E}_{32}$ and $\Delta \mathrm{G}_{\mathrm{hyd}}\left(\mathrm{M}^{3+}\right.$, Marcus, corrected $)$ \\
\hline $\mathrm{Tm}^{2+}$ & $\mathrm{N} / \mathrm{A}$ & N/A & N/A & N/A & $\underline{-1580}$ & from $\mathrm{E}_{32}$ and $\Delta \mathrm{G}_{\mathrm{hyd}}\left(\mathrm{M}^{3+}\right.$, Marcus, corrected $)$ \\
\hline $\mathrm{V}^{2+}$ & -1825 & -1913 & $\mathrm{~N} / \mathrm{A}$ & $\mathrm{N} / \mathrm{A}$ & -1913 & Marcus corrected value \\
\hline $\mathrm{Yb}^{2+}$ & -1510 & -1598 & N/A & N/A & -1598 & Marcus corrected value \\
\hline $\mathrm{Zn}^{2+}$ & -1955 & -2043 & -2022 & -2048 & -2043 & Marcus corrected value \\
\hline
\end{tabular}

${ }^{a}$ Numbers where previous data are unavailable in the compilations by Noyes, Marcus, and Fawcett are marked bold and underlined; numbers changed by more than $20 \mathrm{~kJ} / \mathrm{mol}$ are marked in bold. ${ }^{\mathrm{b}}$ Values reported by Fawcett were converted from conventional data using $\Delta \mathrm{G}_{\mathrm{hyd}}\left(\mathrm{H}^{+}\right)=-1100 \mathrm{~kJ} / \mathrm{mol}$. 
Table 1 and Table 2 show the new values of $\Delta \mathrm{G}_{\text {hyd }}$ together with those of Marcus, Noyes, and Fawcett, where available, for comparison. Values marked bold differ substantially from previously reported numbers, and values marked bold and underlined are new. The notes to the right describe how the values were obtained, either by correcting the Marcus values or by using the thermochemical cycle of Equation (2). Of particular interest are the new values for $3 \mathrm{~d} \mathrm{M}^{3+}$ ions, discussed further below. It should be noted that the conventional values tabulated by Fawcett generally resemble the values by Marcus, and thus they are generally similar to the values obtained in the present work after correcting to the new consensus $\Delta \mathrm{G}_{\text {hyd }}\left(\mathrm{H}^{+}\right)=-1100 \mathrm{~kJ} / \mathrm{mol}$.

Figure 3 compares the new values of $\Delta \mathrm{G}_{\text {hyd }}$ with those previously tabulated by Marcus and Noyes where data from the latter two authors are available (as mentioned, the data tabulated by Fawcett generally resemble those by Marcus shifted by a few $\mathrm{kJ} / \mathrm{mol}$ ). Figure 3A and 3B compare $\Delta \mathrm{G}_{\text {hyd }}$ for $\mathrm{M}^{3+}$ ions from this work with those reported by Noyes and Marcus, respectively. Figure 3D and $\mathbf{3 E}$ compare $\Delta \mathrm{G}_{\text {hyd }}$ for $\mathrm{M}^{2+}$ ions from this work with those reported by Marcus and Noyes, respectively. The agreement is generally good; however for $\mathrm{M}^{3+}$ ions, $\mathrm{Au}^{3+}$ and $\mathrm{Cr}^{3+}$ values calculated from the thermochemical cycle differ substantially from the values reported previously by Marcus ${ }^{10,11}$. Similarly, the tabulated $\Delta \mathrm{G}_{\text {hyd }}\left(\mathrm{Pd}^{2+}\right)$ by Noyes $(-2397 \mathrm{~kJ} / \mathrm{mol})$ also differs substantially from the value obtained in this work after correcting the value by Marcus $(-1998 \mathrm{~kJ} / \mathrm{mol})$. Below, it argued based on trend comparisons that the new values reported in this work are accurate. When the three conflicting data points for $\mathrm{Pd}^{2+}, \mathrm{Au}^{3+}$, and $\mathrm{Cr}^{3+}$ are removed, $\mathrm{R}^{2}=0.99-1.00$ for the comparison of data from this work and those compiled by Marcus and Noyes (Figure 3C and Figure 3F). The agreement confirms the expectation that the new data derived in this work (marked bold in Table 1 and Table 2), which were not previously reported by Noyes, Fawcett or Marcus, should have a similar accuracy as the experimental numbers. 

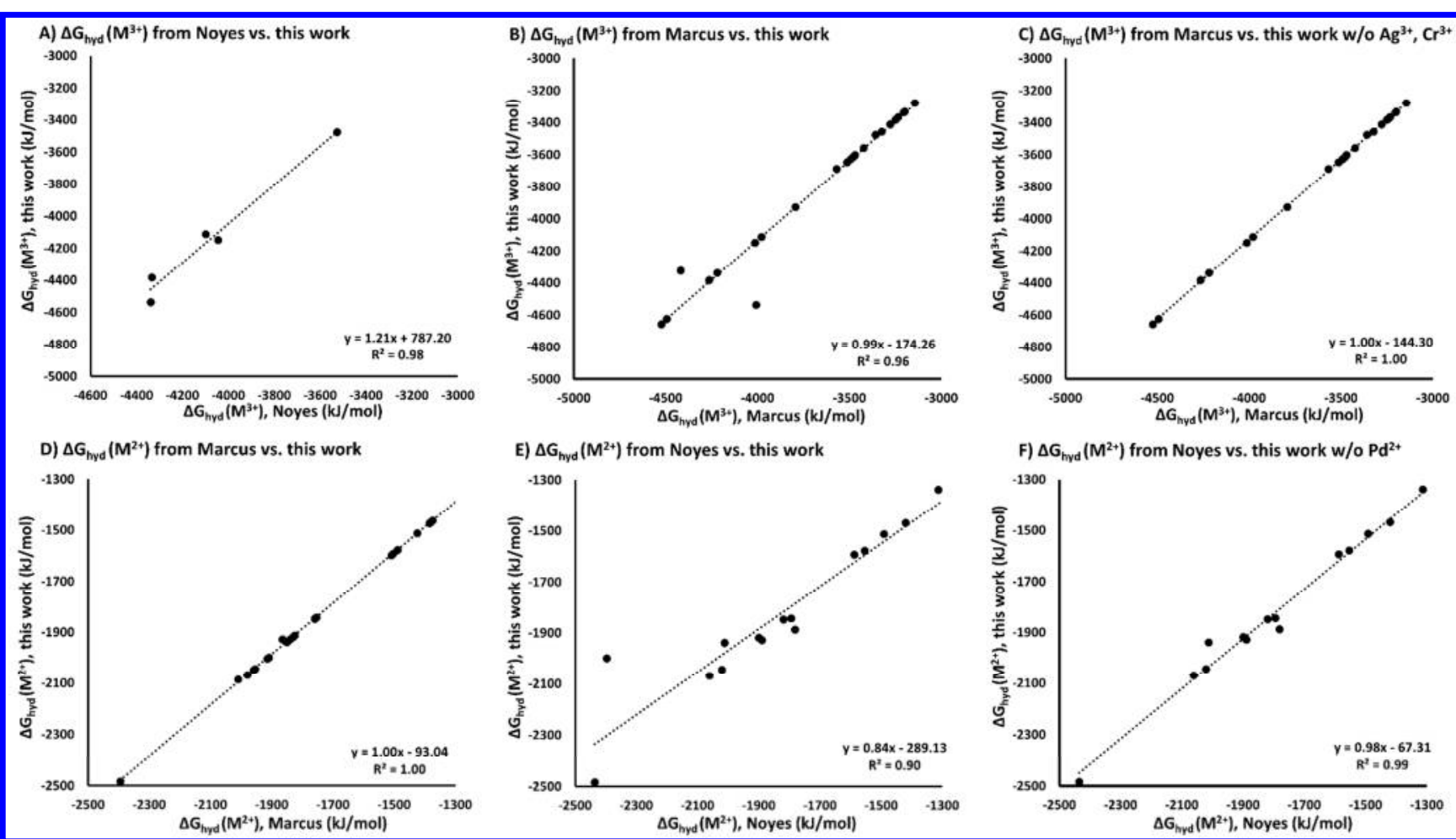

Figure 3. A) Comparison of free energies of hydration for $\mathrm{M}^{3+}$ ions from this work with those reported by Noyes. B) Same compared with values reported by Marcus. C) Same but with the values for $\mathrm{Cr}^{3+}$ and $\mathrm{Ag}^{3+}$ removed from the comparison. D) Comparison of free energies of hydration for $\mathrm{M}^{2+}$ ions from this work with those reported by Marcus. E) Same compared with values reported by Noyes. F) Same, but with the value for $\mathrm{Pd}^{2+}$ removed from the comparison.

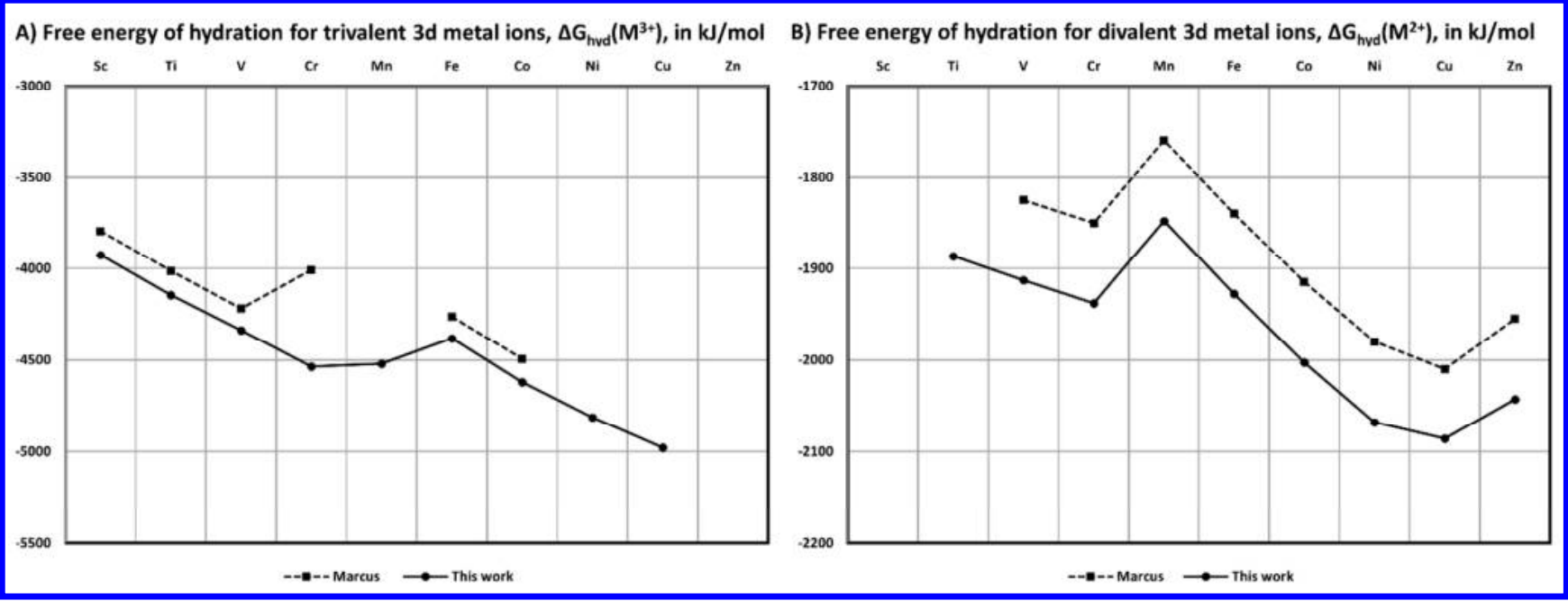

Figure 4. A) Free energy of hydration for $3 \mathrm{~d} \mathrm{M}^{3+}$ ions from this work and from Marcus. B) Free energy of hydration for $3 \mathrm{~d} \mathrm{M}^{2+}$ ions from this work and from Marcus ${ }^{10,11}$. 
We now discuss some chemical implications of the $\Delta \mathrm{G}_{\text {hyd }}$ values not reported before. Of particular interest is the trend in the behavior of $\Delta \mathrm{G}_{\mathrm{hyd}}$ for the same oxidation state across the $\mathrm{d}$ transition series. Figure 4 shows the values of $\Delta \mathrm{G}_{\mathrm{hyd}}$ from this work and from the compilation by Marcus for the $3 \mathrm{~d} \mathrm{M}^{3+}$ (Figure 4A) and $\mathrm{M}^{2+}$ ions (Figure 4B). The entropy of hydration, $\Delta \mathrm{S}_{\mathrm{hyd}}$, is similar for the ions of the same charge due to their similar overall effect on bulk water structure ${ }^{11}$. Thus, the free energies are expected to follow closely the trend for $\Delta \mathrm{H}_{\text {hyd }}$.

For the $3 \mathrm{~d} \mathrm{M}^{3+}$ ions seen in Figure 4A, five values were compiled by Marcus. Based on the thermochemical cycle calculations, a total of nine of the ten $\Delta \mathrm{G}_{\text {hyd }}$ values are now available on a consistent scale (the value for $\mathrm{Zn}^{3+}$ remains elusive due to the instability of this redox state). As expected, $\Delta \mathrm{G}_{\mathrm{hyd}}$ becomes more negative toward the right of the $3 \mathrm{~d}$ transition series as the increased effective nuclear charge makes the lone pairs of water molecules associate more strongly with the metal ions. In addition, deviations from linearity result from the effect of the occupation of $e_{g}$ vs. $t_{2 g}$ orbitals, which also translates into the ligand field stabilization energy. Occupation of $\mathrm{e}_{\mathrm{g}}$ orbitals lowers the ligand field stabilization energy and reduces the association with water lone pairs due to the increased repulsion with d-electrons in the $e_{g}$ orbitals that point directly towards the water lone pairs. These two effects are well-known and described in text books for $\Delta \mathrm{H}_{\text {hyd }}\left(\mathrm{M}^{2+}\right)^{35}$, but not previously for $\mathrm{M}^{3+}$. The notable difference between the two series is the difference in one d-electron, which leads the bump to be at $\mathrm{Cr}^{3+}$ rather than at $\mathrm{V}^{2+}$; both being $\mathrm{d}^{3}$ systems with maximal ligand field stabilization energy for the first half of the series.

The $\Delta \mathrm{G}_{\text {hyd }}\left(\mathrm{Cr}^{3+}\right)$ value reported by Marcus can now be seen to be inconsistent with these trends, whereas the new value derived here (Table 1) is fully consistent with the expected physical effect of the ligand field. For the same reason, the new value for $\mathrm{Mn}^{3+}(-4520 \mathrm{~kJ} / \mathrm{mol})$ is excellently on the expected trend, having a smaller ligand field stabilization energy $\left(d^{4}\right)$ but a higher effective nuclear charge making its value only slightly higher than that of $\mathrm{Cr}^{3+} \cdot \mathrm{Mn}^{3+}$ has, as far as the author is aware, not been reported before probably due to the instability of the species in solution. $\Delta \mathrm{G}_{\text {hyd }}\left(\mathrm{Fe}^{3+}\right)$ forms a local maximum in the trend directly explained from its zero ligand field stabilization energy, whereas subsequent metal ions, notably the new consistent values for $\mathrm{Ni}^{3+}$ and $\mathrm{Cu}^{3+}$, monotonously increase their ligand field stabilization energy to make hydration more favorable. From the new established trend in Figure $\mathbf{4 A}$, one can estimate that $\Delta \mathrm{G}_{\mathrm{hyd}}$ of the experimentally elusive $\mathrm{Zn}^{3+}$ is smaller than $-4900 \mathrm{~kJ} / \mathrm{mol}$ on the scale applied here; this ion has so far never been observed and is possibly only of 
theoretical interest. If one considers its likely Jahn-Teller distortion, $\Delta \mathrm{G}_{\text {hyd }}\left(\mathrm{Zn}^{3+}\right)$ will most likely be between -5000 and $-5100 \mathrm{~kJ} / \mathrm{mol}$; this value could probably be estimated theoretically.

In terms of $\Delta \mathrm{G}_{\text {hyd }}\left(\mathrm{M}^{2+}\right.$ ), a consistent series (Figure 4B) is now available for the entire $3 \mathrm{~d}$ transition series except $\mathrm{Sc}^{2+}$, with the value for $\mathrm{Ti}^{2+}$ derived from the thermochemical cycle being excellently on the expected trend. The overall trend in $\Delta \mathrm{G}_{\text {hyd }}\left(\mathrm{M}^{2+}\right)$ is essentially identical to the known trend in $\Delta \mathrm{H}_{\text {hyd }}\left(\mathrm{M}^{2+}\right)^{35}$ due to the similar hydration entropy of the species, and follows from the same arguments as applied above. More generally, the excellent trends in Figure 4 show that trend properties of hydrated metal ions derive mainly from electronic structure effects of the first hydration sphere, with additional water having a relatively similar constant contribution.

Using similar considerations, we can now also resolve the conflicting data on $\Delta \mathrm{G}_{\text {hyd }}\left(\operatorname{Pd}^{2+}\right)$. Simple interpolation from $\mathrm{Ag}^{2+}(-1928 \mathrm{~kJ} / \mathrm{mol})$ and $\mathrm{Cd}^{2+}(-1843 \mathrm{~kJ} / \mathrm{mol})$ gives a linear trend with the value $-1998 \mathrm{~kJ} / \mathrm{mol}$, which fits well to the loss of ligand field stabilization energy toward the far right of the $4 \mathrm{~d}$ transition series, as also seen for the $\mathrm{Ni}^{2+} / \mathrm{Zn}^{2+}$ comparison, and with energies similar to those of the $3 \mathrm{~d}$ transition series. This strongly argues against the alternative value $-2397 \mathrm{~kJ} / \mathrm{mol}$, which is far outside the range expected for the series as a whole and is not physically meaningful from a trend comparison viz. the above discussion. The trend using $-1998 \mathrm{~kJ} / \mathrm{mol}$ also interestingly predicts that the strong Jahn-Teller distortion that produces the anomalously negative $\Delta \mathrm{G}_{\mathrm{hyd}}\left(\mathrm{Cu}^{2+}\right)$ is essentially absent in $\mathrm{Ag}^{2+}$, although this remains to be confirmed experimentally.

\section{CONCLUSION}

In summary, this paper has used the conventions on the SHE and free energy of hydration of the proton and a thermochemical cycle that relies on cancellation of the difficult metal states, to derive free energies of hydration in Table $\mathbf{1}$ and $\mathbf{2}$ that are all consistent with each other within the thermochemical cycle, as they should be. The use of trend comparisons enables the major revision of some previous values, notably for $\mathrm{Au}^{3+}, \mathrm{Cr}^{3+}$, and $\mathrm{Pd}^{2+}$ and reveals the first complete trend for the hydration from $\mathrm{Sc}^{3+}$ to $\mathrm{Cu}^{3+}$ which is physically meaningful and well explained by the combination of effective nuclear charge and $e_{g}$ orbital occupation effects. Entirely new values have been obtained for many ions such as $\mathrm{Ag}^{3+}, \mathrm{Cu}^{3+}, \mathrm{Mn}^{3+}, \mathrm{Ni}^{3+}, \mathrm{Au}^{2+}$, and lanthanide $\mathrm{M}^{2+}$ states, some of which are very hard to produce experimentally whereas others should not be. The new values should hopefully be of 
use in other thermochemical calculations, for interpreting the aqueous behavior of the involved metal ions, and as benchmarks for theoretical chemistry.

\section{SUPPORTING INFORMATION}

The Supporting Information file contains Table S1 with experimental standard half reduction potentials (in V) and first, second, and third ionization potentials (in eV) used for the calculations done in this work. This file is available free of charge at http://pubs.acs.org

\section{ACKNOWLEDGEMENTS}

The author states that there is no financial support associated with the present work.

\section{REFERENCES}

(1) Collins, K. D. Ion Hydration: Implications For Cellular Function, Polyelectrolytes, And Protein Crystallization. Biophvs. Chem. 2006, 119, 271-281.

(2) Rode, B. M.; Schwenk, C. F.; Hofer, T. S.; Randolf, B. R. Coordination And Ligand Exchange Dynamics Of Solvated Metal Ions. Coord.Chem. Rev. 2005, 249, 2993-3006.

(3) Kepp, K. P. Alzheimer's Disease: How Metal Ions Define B-Amyloid Function. Coordination Chemistry Reviews 2017, 351, 127-159.

(4) Woodson, S. A. Metal Ions And RNA Folding: A Highly Charged Topic With A Dynamic Future. Curr. Opin. Chem. Biol. 2005, 9, 104-109.

(5) Carter, K. P.; Young, A. M.; Palmer, A. E. Fluorescent Sensors For Measuring Metal Ions In Living Systems. Chem. Rev. 2014, 114, 4564-4601.

(6) Marenich, A. V; Ho, J.; Coote, M. L.; Cramer, C. J.; Truhlar, D. G. Computational Electrochemistry: Prediction Of Liquid-Phase Reduction Potentials. Phys. Chem. Chem. Phys. 2014, 16, 15068-15106.

(7) Ho, J. Are Thermodynamic Cycles Necessary For Continuum Solvent Calculation Of ${ }_{\mathrm{P}} \mathrm{K}_{\mathrm{a}} \mathrm{s}$ And Reduction Potentials? Phvs. Chem. Chem. Phvs. 2015, 17, 2859-2868.

(8) Jensen, K. P. Improved Interaction Potentials For Charged Residues In Proteins. J. Phys. Chem. 
$B$ 2008, 112, 1820-1827.

(9) Jensen, K. P.; Jorgensen, W. L. Halide, Ammonium, And Alkali Metal Ion Parameters For Modeling Aqueous Solutions. J. Chem. Theorv Comput. 2006, 2, 1499-1509.

(10) Marcus, Y. Thermodynamics Of Solvation Of Ions. Part 5.-Gibbs Free Energy Of Hydration At 298.15 K. J. Chem. Soc. Faradav Trans. 1991, 87, 2995-2999.

(11) Marcus, Y. A Simple Empirical Model Describing The Thermodynamics Of Hydration Of Ions Of Widely Varying Charges, Sizes, And Shapes. Biophvs. Chem. 1994, 51, 111-127.

(12) Marcus, Y. The Thermodynamics Of Solvation Of Ions. Part 4.-Application Of The Tetraphenylarsonium Tetraphenylborate (Tatb) Extrathermodynamic Assumption To The Hydration Of Ions And To Properties Of Hydrated Ions. J. Chem. Soc. Faraday Trans. 1 Phys. Chem. Condens. Phases 1987, 83, 2985-2992.

(13) Noyes, R. M. Thermodynamics Of Ion Hydration As A Measure Of Effective Dielectric Properties Of Water. J.Am.Chem.Soc. 1962, 84, 513-522.

(14) Rosseinsky, D. R. Electrode Potentials And Hydration Energies. Theories And Correlations. Chem Rev. 1965, 65, 467-490.

(15) Fawcett, W. R. Thermodynamic Parameters For The Solvation Of Monatomic Ions In Water. $J$. Phvs. Chem. B 1999, 103, 11181-11185.

(16) Latimer, W. M.; Pitzer, K. S.; Slansky, C. M. The Free Energy Of Hydration Of Gaseous Ions, And The Absolute Potential Of The Normal Calomel Electrode. In Molecular Structure And Statistical Thermodynamics: Selected Papers Of Kenneth S Pitzer; World Scientific, 1993; Pp 485-489.

(17) Latimer, W. M. Single Ion Free Energies And Entropies Of Aqueous Ions. J. Chem. Phys. 1955, $23,90-92$.

(18) Trasatti, S. On The Concept And The Possibility Of Experimental Determination Of Absolute Electrode Potentials. L.Chem. Phvs. 1978, 69, 2938-2939.

(19) Trasatti, S. The Absolute Electrode Potential: An Explanatory Note (Recommendations 1986). Pure Anpl. Chem. 1986, 58, 955-966.

(20) Gomer, R.; Tryson, G. An Experimental Determination Of Absolute Half $\square$ Cell Emf’s And 
Single Ion Free Energies Of Solvation. L.Chem.Phvs. 1977, 66, 4413-4424.

(21) Tissandier, M. D.; Cowen, K. A.; Feng, W. Y.; Gundlach, E.; Cohen, M. H.; Earhart, A. D.; Coe, J. V; Tuttle, T. R. The Proton's Absolute Aqueous Enthalpy And Gibbs Free Energy Of Solvation From Cluster-Ion Solvation Data. J.Phvs. Chem.A 1998, 102, 7787-7794.

(22) Kelly, C. P.; Cramer, C. J.; Truhlar, D. G. Aqueous Solvation Free Energies Of Ions And IonWater Clusters Based On An Accurate Value For The Absolute Aqueous Solvation Free Energy Of The Proton. L Phys. Chem. B 2006, 110, 16066-16081.

(23) Trasatti, S. The Concept Of Absolute Electrode Potential An Attempt At A Calculation. $J$. Electroanal. Chem. Interfacial Electrochem. 1974, 52, 313-329.

(24) Fawcett, W. R. The Ionic Work Function And Its Role In Estimating Absolute Electrode Potentials. Langmuir 2008, 24, 9868-9875.

(25) Zhan, C.-G.; Dixon, D. A. Absolute Hydration Free Energy Of The Proton From FirstPrinciples Electronic Structure Calculations. L Phvs. Chem.A 2001, 105, 11534-11540.

(26) Farrell, J. R.; Mctigue, P. Precise Compensating Potential Difference Measurements With A Voltaic Cell: The Surface Potential Of Water. J. Electroanal. Chem. Interfacial Electrochem. 1982, 139, 37-56.

(27) Randles, J. E. B. The Real Hydration Energies Of Ions. Trans. Faradav Soc. 1956, 52, 15731581.

(28) Krishtalik, L. I. The Surface Potential Of Solvent And The Intraphase Pre-Existing Potential. Russ.J.Electrochem. 2008, 44, 43-49.

(29) Parfenyuk, V. I. Surface Potential At The Gas-Aqueous Solution Interface. Colloid J. 2002, 64, $588-595$.

(30) John Rumble. CRC Handbook Of Chemistry And Physics, 98th Edition; CRC Press 1lc, 2017.

(31) Bratsch, S. G. Standard Electrode Potentials And Temperature Coefficients In Water At 298.15 K. J. Phys. Chem. Ref. Data 1989, 18, 1-21.

(32) Colominas, C.; Luque, F. J.; Teixidó, J.; Orozco, M. Cavitation Contribution To The Free Energy Of Solvation.: Comparison Of Different Formalisms In The Context Of MST Calculations. Chem. Phvs. 1999, 240, 253-264. 
(33) Mei, H. S.; Coker, D. F. Quantum Molecular Dynamics Studies Of $\mathrm{H}_{2}$ Transport In Water. $J$. Chem. Phys. 1996, 104, 4755-4767.

(34) Floris, F. M.; Selmi, M.; Tani, A.; Tomasi, J. Free Energy And Entropy For Inserting Cavities In Water: Comparison Of Monte Carlo Simulation And Scaled Particle Theory Results. J. Chem. Phys. 1997, 107, 6353-6365.

(35) Atkins, P.; Overton, T. Shriver And Atkins' Inorganic Chemistry; Oxford University Press, Oxford, 2010. 


\section{TOC graphic}

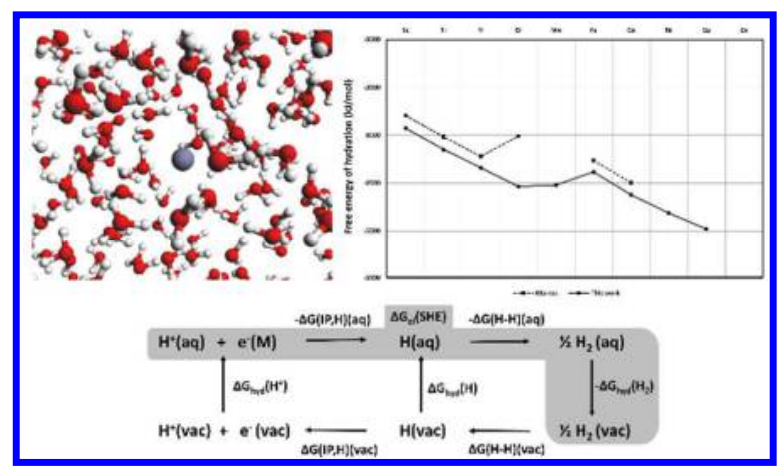




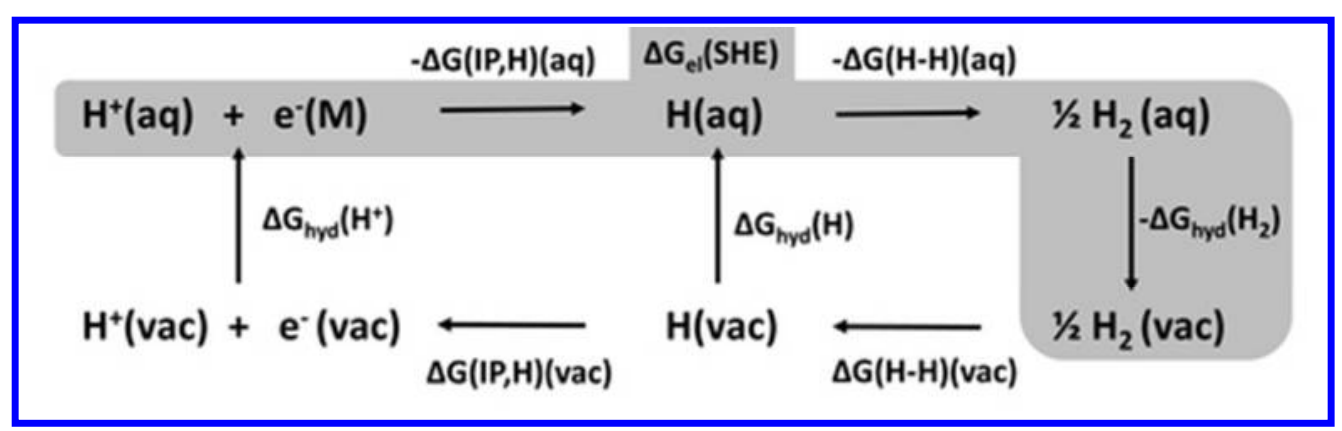

Figure 1

$43 \times 13 \mathrm{~mm}(300 \times 300$ DPI $)$ 


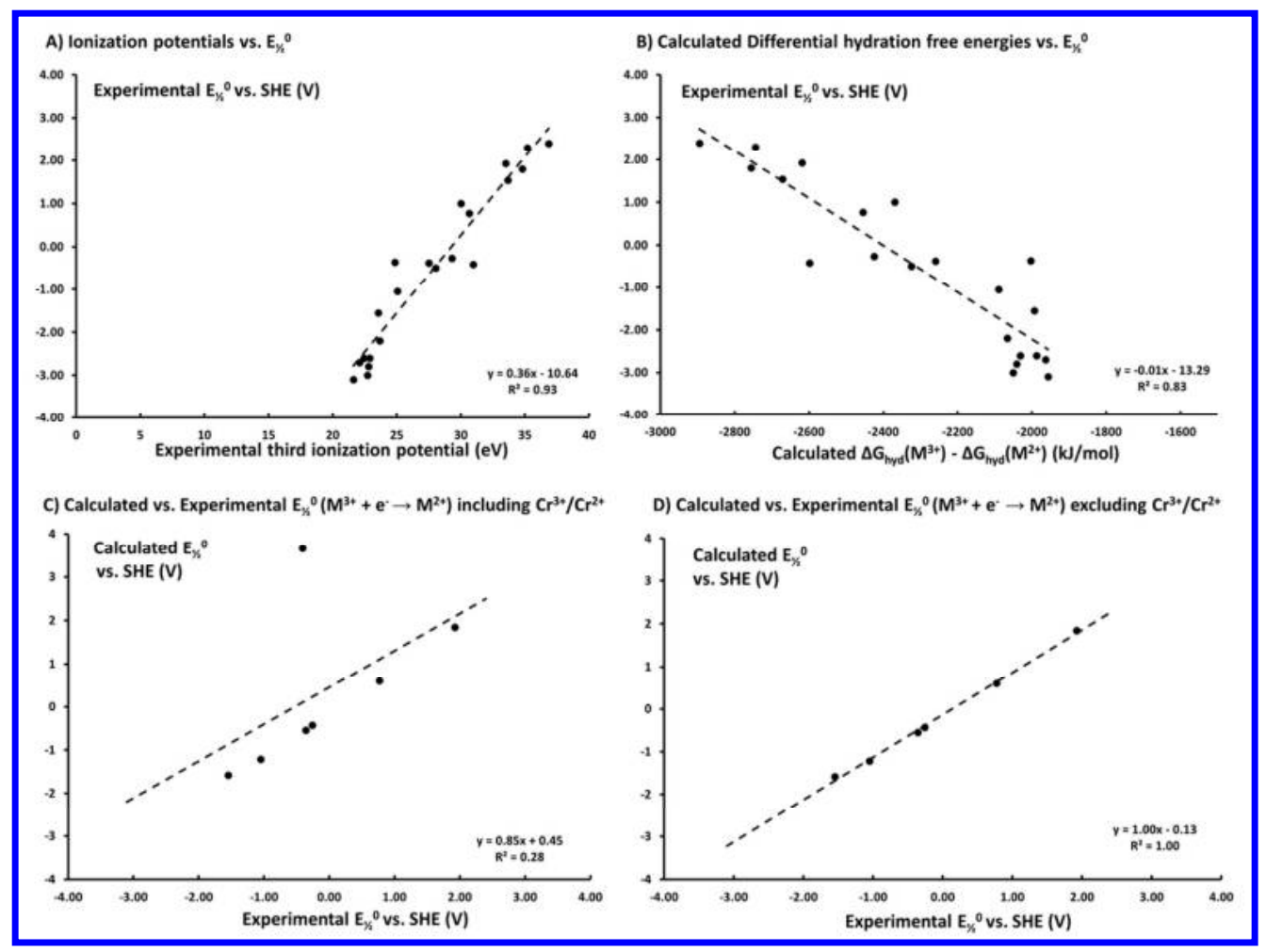

Figure 2

$107 \times 80 \mathrm{~mm}(300 \times 300 \mathrm{DPI})$ 


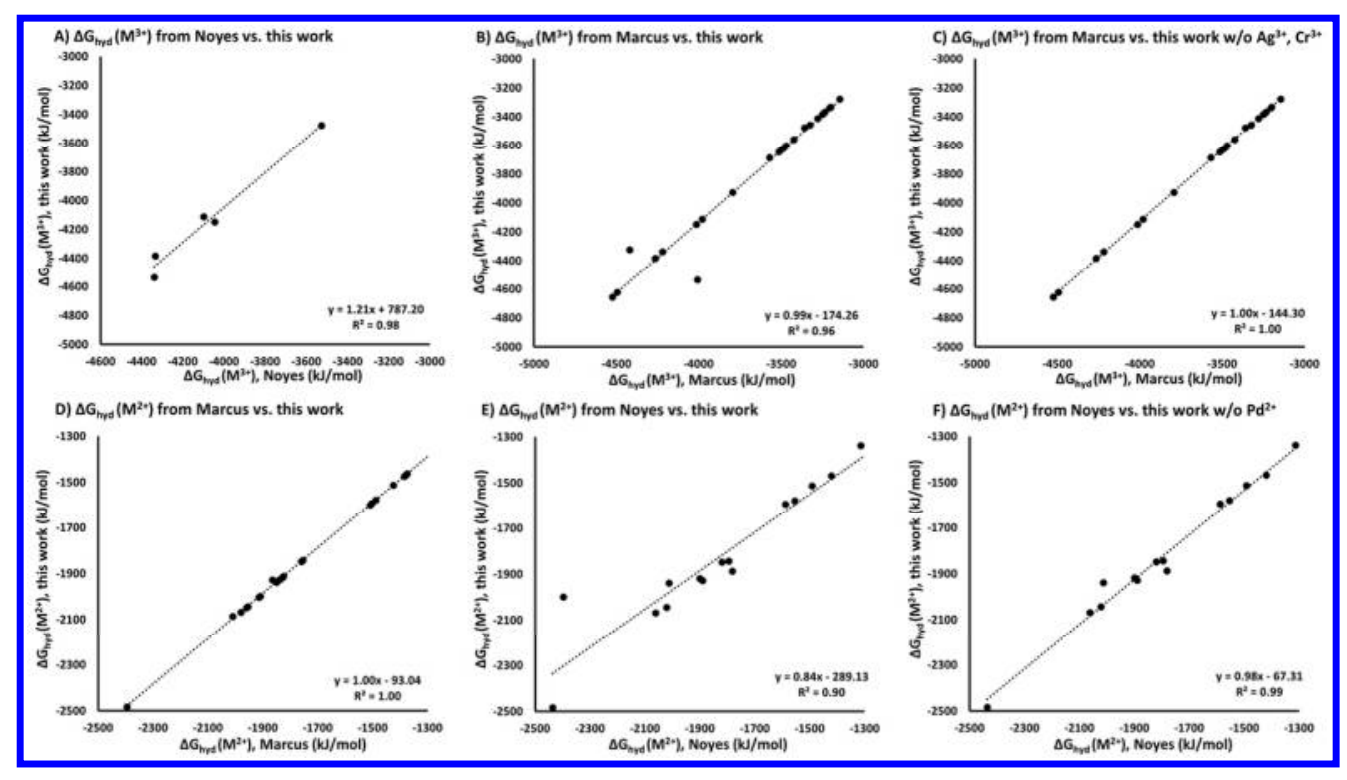

Figure 3

$107 \times 60 \mathrm{~mm}(300 \times 300$ DPI) 


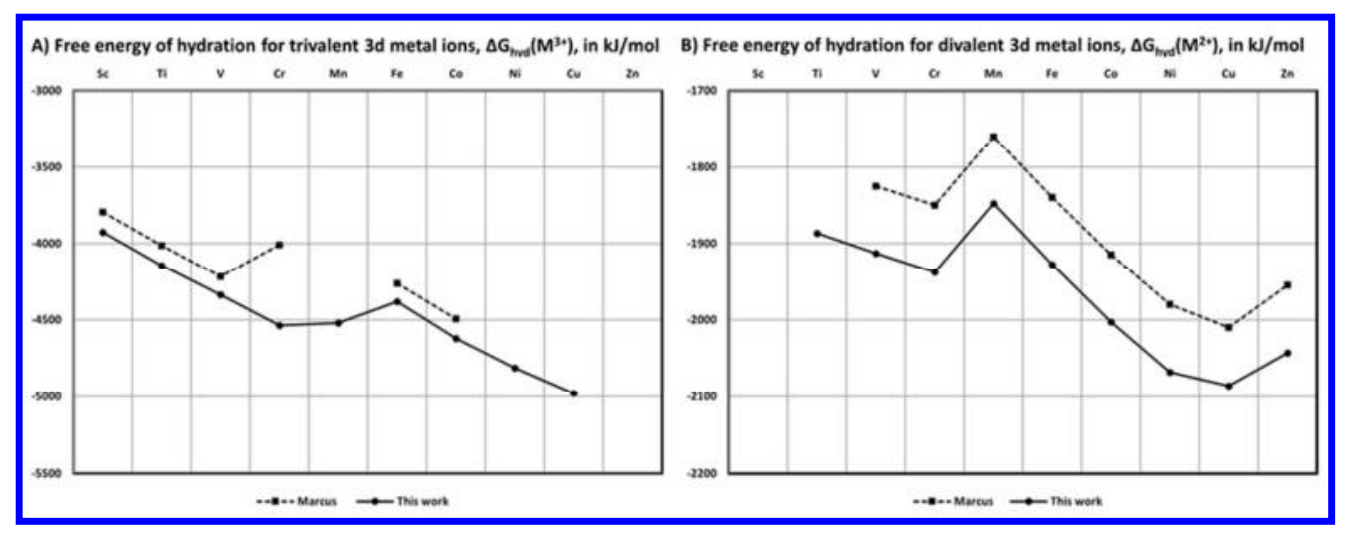

Figure 4

$72 \times 27 \mathrm{~mm}(300 \times 300$ DPI $)$ 


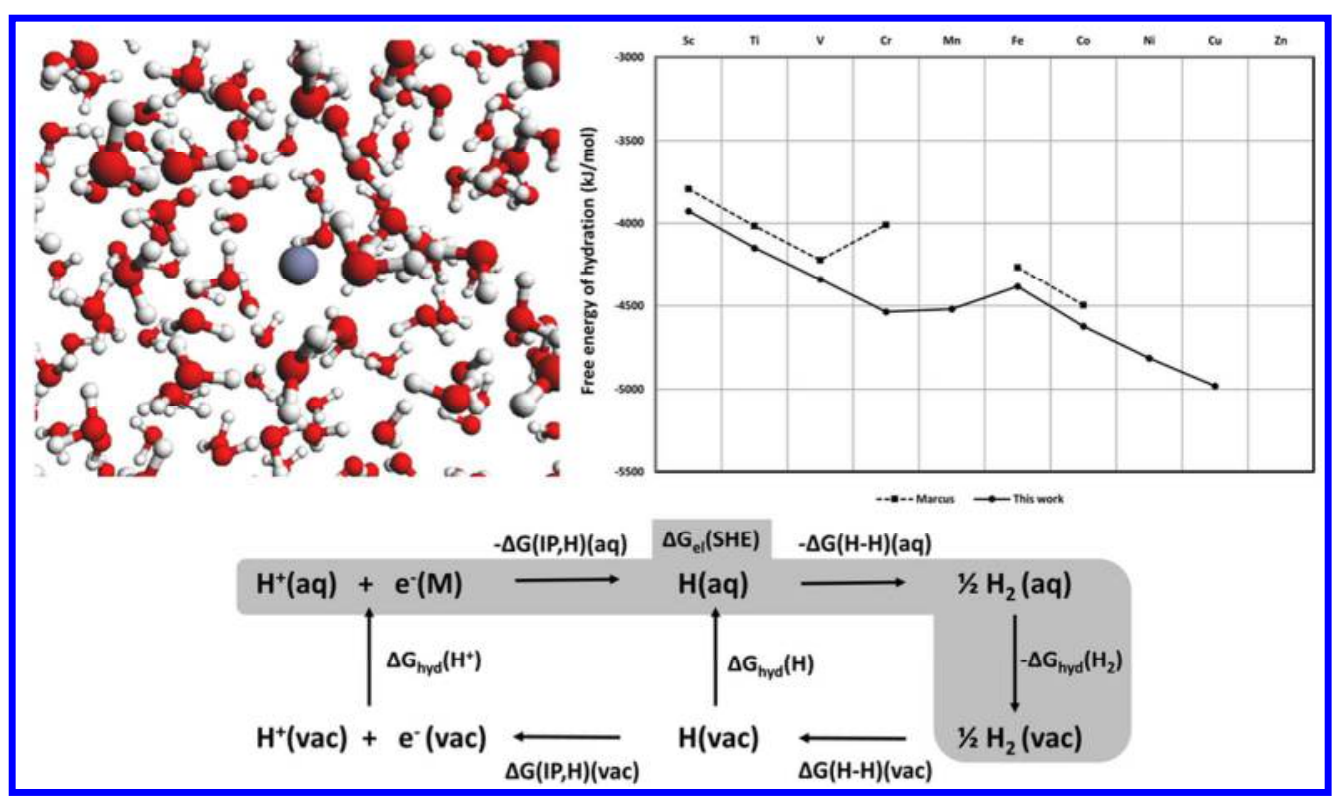

TOC graphic

$44 \times 25 \mathrm{~mm}(600 \times 600$ DPI $)$ 